\title{
Defining the Scope of Professional Subcontracting under the EPC General Contracting Mode
}

\author{
Liu Liu \\ Tianjin University of Technology, Tianjin 300384, China \\ sanjingtuzi@163.com
}

Keywords: EPC general contracting model, professional subcontracting management, labor service.

\begin{abstract}
EPC general contracting mode was widely used in many large engineering construction at home and abroad, with specialized subcontracting management as the mainstay, the mutually beneficial management model of labor service enterprises has become very popular. However, the relevant laws and regulations have very vague definition on the subcontracting of construction projects. This paper classified the different qualifications of EPC general contracting enterprises and analyzed the characteristics and scope of the subcontracting, further educed the basic conditions for legal subcontracting, with the expectation to benefit both parties.
\end{abstract}

\section{Introduction}

As one of the most typical and widely used models in the general contract mode, EPC has become the mainstream construction model in the field of international large-scale engineering construction. Subcontracting is the most widely used form of EPC contract1. Studying the scope of professional subcontracting of general contractors with different qualifications can improve their technical capabilities and management level so as to achieve good development in fierce market competition. The relevant regulations and contract documents issued by the state are very vague about the subcontracting of construction projects, making the subcontracting of the construction market always chaotic. Therefore, it is necessary to study the definition of the scope of professional subcontracting under the EPC general contracting mode.

In the existing researches, Xu Ning2 and Liu Jieling3 studied the definition and legal consequences of illegal construction subcontracting; Zhang Bingqiang4 analyzed the project subcontracting system and pointed out that the related laws and regulations need to be improved; He Xing5 picked out the common legal issues in the EPC subcontracting management. However, none of these scholars defined the scope of the professional subcontracting of the general contractors with different qualifications. Therefore, combined with the existing research, this paper will discuss the subcontracting scope of the contract enterprises with different qualifications under the EPC general contracting mode, and further draw the basic conditions for the legal subcontracting, in order to provide references for the contracting parties in practice.

Considering about the common construction project of EPC general contracting model and the different qualifications of the general contractors, they can be divided into the following three categories: the design oriented EPC general contracting enterprises; the construction oriented EPC general contracting enterprises; the EPC general contracting enterprises with both design and construction qualification.

\section{Subcontracting of the Design Oriented General Contracting Enterprises}

\subsection{The Advantages of the Design Oriented General Contracting Enterprises}

1. More conducive to saving project investment

Design oriented EPC general contracting enterprises always run through the whole life cycle of the project, which greatly inspired the enthusiasm of designers and made full use of their advantages, greatly reducing the project cost and saving engineering investment.

2. More conducive to shorten the project duration 
It is easy to achieve a smooth connection between design and construction, which is beneficial to speed up the progress of the project and shorten the duration of the project on the basis of the guarantee period.

3. More conducive to ensuring the quality of the project

As the design is the key link of the whole project, it determines the quality of the construction6. The design oriented contractors have been involved in the design since the beginning, so that they can integrate the data in building materials and other aspects in design. This will not only be able to better control the total cost of the project, but also to ensure the quality of the project.

\subsection{The Subcontracting Scope of the Design Oriented General Contracting Enterprises}

The general contractor enterprises can implement their own design and construction within the scope of qualification certificate permission, they can also subcontract the design or construction of the project to the qualified enterprises under the agreement of the owner.

When a general contracting project was undertaken by a design oriented general contracting enterprise, the construction business should be subcontracted to a company with corresponding construction qualification. However, a general contracting enterprise should not subcontract the general contracting project, nor subcontract the whole design and construction business to other units. The design oriented general contracting enterprises should not subcontract the main part of the design business to other units.

\section{Subcontracting of the Construction Oriented General Contracting Enterprises}

\subsection{The Advantages of the Construction Oriented General Contracting Enterprises}

1. More conducive to the management of the project

The construction enterprises have many professional on-site management personnel, they have rich experience in construction and procurement, and have good judgment on the feasibility of project design and program economy. Therefore, it can work in a timely manner to carry out linkage design, construction and procurement in the early stage of design, which is conducive to the project progress, project investment and project quality management.

2. More conducive to improve the construction process

Because of the strength of the construction unit, the exquisite construction technology and the perfect construction process are all the successful elements which it must possess as an advantageous construction enterprise7. And the dominant position of the construction unit also determines the relationship between revenue and responsibility, which makes the construction unit can choose the most mature construction technology and the most feasible construction program to achieve the quality and cost requirements with the least resources.

3. More conducive to optimize the construction period

A great deal of communication and coordination work is needed during the process of project implementation. However, construction enterprise managers have accumulated rich experience in coordinating with design institutes and purchasing units in the practice of project site management, which plays a significant role in exploiting the advantages of the EPC general contracting.

\subsection{The Subcontracting Scope of the Construction Oriented General Contracting Enterprises}

The general contractor enterprises can implement their own design and construction within the scope of qualification certificate permission, they can also subcontract the design or construction of the project to the qualified enterprises under the agreement of the owner.

If a construction qualification company accepts the general contracting project, it should subcontract the design business of the general contracting project to a company with corresponding design qualification. The EPC contractors must strengthen the management of subcontracting. They should not subcontract the general contracting project, nor subcontract the whole design and construction business to other units. 


\section{Subcontracting of the Enterprises WITH Both Design and Construction Qualification}

\subsection{The Advantages of the Enterprises With Both Design and Construction Qualification}

1. More conducive to overcoming the contradiction between design, purchase and construction

This kind of EPC general contracting enterprises have the ability to coordinate the three aspects of EPC project design, procurement and construction. The three parts must obey the unified command of the project manager and they are a community of interests. So this mode can realize the unified management and coordination of all aspects, and then overcome the contradiction between design, procurement and construction.

2. More conducive to control the progress of the construction project

In the EPC general contracting, design, procurement and construction can be conducted with a cross-cutting dialectical. Find out the key path to influence the time limit according to the construction order, and focus on monitoring the process on the key path. Decompose the whole project with a molecular item, coordinate the design, procurement and construction. This effectively shortens the construction cycle.

3. More conducive to control the quality of the construction project

Because of the strong technical ability, this kind of EPC general contractors pay more attention to play their own technological superiority, so they can solve the problems quality and quickly. They also pay more attention to the interface management of each link and implement the closed loop management by making the quality assurance system. As the design, procurement and construction are charged by one contractor, it is beneficial to find out the best solution so that the quality of the project will be well controlled.

4. More conducive to reduce the risk of owners

Since the owners no longer directly manage the construction of the project under EPC general contracting mode, the responsibility of guaranteeing the quality, controlling the cost and handing over the work is transferred to the EPC general contractor, the risk of the owners is greatly reduced8.

\subsection{The Subcontracting Scope of the Enterprises With Both Design and Construction Qualification}

The EPC general contracting enterprise not only has the design qualification but also has the construction qualification which is adapted to the scale of the project. The general contractor enterprises can implement their own design and construction within the scope of qualification certificate permission, they can also subcontract the design or construction of the project to the qualified enterprises under the agreement of the owner.

When a general contracting project was undertaken by a general contracting enterprise which has both design and construction qualification, the contractors should strengthen the management of subcontracting. They should not subcontract the general contracting project, nor subcontract the whole design and construction business to other units. If the contractors carry out the design by themselves, they should not subcontract the main part of the design business to other units. If the contractors carry out the construction by themselves, they should not subcontract the main part of the construction business to other units.

\section{Conclusion}

The qualification is the legal valid certificate for the construction enterprises to enter into the construction market and carry out the operation and production activities. Based on the literature and the relevant laws and regulations, this paper studied the subcontracting scope of the contract enterprises with different qualifications under the EPC general contracting mode. Four basic conditions for a legal subcontracting are to be obtained: contractual agreement or approved by the construction unit; only partial non-principal work can be subcontracted; subcontractors must have the appropriate qualifications; the subcontractor may not subcontract the project again. However, due to the difficulty of obtaining data in the course of the research, we failed to combine more practical cases to verify the subcontracting scope of the EPC general contracting enterprises with different qualifications. 


\section{References}

[1]. Yong Wang, "On the problems and Countermeasures of the implementation of EPC general contract,” Construction Economy, 2009, pp. 81 84.

[2]. Ning Xu, "Definition of construction project illegal subcontract and its legal consequences," Master's thesis, Xiangtan University, 2013.

[3]. Jieling Liu, "Illegal subcontracting and its management in construction," Modern Economic Information, 2013, pp. 358 359.

[4]. Bingqiang Zhang and Yongzhao Wang, "The legal subcontract under the project general contract mode,” China Tendering, 2016, pp. 25 27.

[5]. Xing He, "Research on legal issues of subcontract management based on EPC mode," Modern Real Estate, 2011, pp. 36 37.

[6]. Hongying Deng, "How to control the construction cost effectively under the EPC general contracting mode,” Building Materials and Decoration, 2016, pp. 187 188.

[7]. Siqin Chen, "Research on design management in EPC general contract model,” Master's thesis, Chongqing University, 2010.

[8]. Huijun Liu, “Advantages of EPC project management mode,” Chinese science and technology information, 2014, pp. 217 219. 